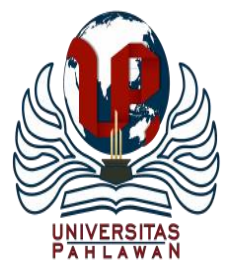

Edukatif : Jurnal Ilmu Pendidikan Volume 3 Nomor 5 Tahun 2021 Halm 3018 - 3025

EDUKATIF: JURNAL ILMU PENDIDIKAN

Research \& Learning in Education

https://edukatif.org/index.php/edukatif/index

\title{
Pengaruh Model Pembelajaran Picture and Picture terhadap Peningkatan Prestasi Belajar Siswa Sekolah Dasar
}

\author{
Dista Praseptia $^{1 凶}$, Zulherman $^{2}$ \\ Univeritas Muhammadiyah Prof. Dr. Hamka, Indonesia ${ }^{1,2}$ \\ E-mail : distap99@ gmail.com ${ }^{1}$, zulherman@uhamka.ac.id ${ }^{2}$
}

\begin{abstract}
Abstrak
Penelitian ini bertujuan untuk dapat mengetahui ada atau tidaknya pengaruh model pembelajaran picture and picture terhadap peningkatan prestasi belajar siswa sekolah dasar pada materi zat tunggal dan zat campuran. Metode penelitian yang digunakan adalah kuantitatif dengan quasi exsperiment yang dirancang dengan menggunakan desain penelitian Pretest dan Posttest Control Group Design. Besar sampel pada penelitian berjumlah 60 siswa yang dibagi menjadi 2 kelompok yaitu kelas V-A yang berjumlah 30 siswa sebagai kelas eksperimen dan V-B yang berjumlah 30 siswa sebagai kelas kontrol. Dalam perhitungan data analisis penelitian menggunakan statistik deskriptif, uji normalitas menggunakan liliefors, homogenitas menggunakan uji fisher, dan hipotesis uji-t. Hasil perhitungan hipotesis menggunakan Uji-t dinyatakan kedua kelas menunjukkan thitung sebesar 4,9414 > ttabel sebesar 2,0021. Sehingga dapat disimpulkan H1 diterima. Berdasarkan hasil penelitian ini dapat dibuktikan bahwa terdapat pengaruh model pembelajaran picture and picture terhadap peningkatan prestasi belajar siswa sekolah dasar pada materi zat tunggal dan zat campuran.
\end{abstract}

Kata Kunci: Model Pembelajaran Picture and Picture, Prestasi Belajar.

\begin{abstract}
This study aims to determine whether or not there is an effect of the picture and picture learning model on improving the learning achievement of elementary school students on single and mixed substances. The research method used is quantitative with a quasi-experimental research design which is designed using a pretest and posttest control group design. The sample size in the study was 60 students who were divided into 2 groups, namely class $V$-A, which consisted of 30 students as the experimental class and $V$ - $B$, which consisted of 30 students as the control class. In calculating research analysis data using descriptive statistics, normality test using liliefors, homogeneity using fisher test, and t-test hypothesis. The results of the calculation of the hypothesis using the t-test stated that both classes showed tcount of $4.9414>$ ttable of 2.0021. So it can be concluded that HI is accepted. Based on the results of this study, it can be proven that there is an effect of the picture and picture learning model on improving the learning achievement of elementary school students on single and mixed substances.
\end{abstract}

Keywords: Model Pembelajaran Picture and Picture, Learning Achievement.

Copyright (c) 2021 Dista Praseptia, Zulherman

$\triangle$ Corresponding author

Email : distap99@gmail.com

DOI : https://doi.org/10.31004/edukatif.v3i5.1073

ISSN 2656-8063 (Media Cetak)

ISSN 2656-8071 (Media Online) 
3019 Pengaruh Model Pembelajaran Picture and Picture Terhadap Peningkatan Prestasi Belajar Siswa Sekolah Dasar - Dista Praseptia, Zulherman

DOI: https://doi.org/10.31004/edukatif.v3i5.1073

\section{PENDAHULUAN}

Dunia saat ini sedang mengalami wabah, pandemi Covid-19 (Coronavirus Disease 2019). Kemunculan virus ini pertama kali ditemukan di Wuhan, China pada akhir Desember 2019. Virus ini menyebar sangat cepat, setelah menyebar ke semua negara termasuk Indonesia hanya dalam beberapa bulan. Seiring dengan jumlah kasus penyebaran virus Covid-19 di Indonesia yang terus meningkat, rupanya berdampak tersendiri bagi dunia pendidikan. Pemerintah telah merilis informasi tentang kebijakan atau tindakan yang dapat diambil selama pandemi virus corona. Kebijakan yang diambil saat ini adalah membatalkan semua kegiatan pengajaran dan kemudian mengubahnya menjadi sistem online (Monica \& Fitriawati, 2020). Pemberitahuan Kemendikbud Nomor 2 dan Peraturan Menteri Nomor 2 Tahun 2020 Nomor 3 Tahun 2020 tentang Pencegahan dan Penanganan Penyakit Virus Corona (Covid19) mewajibkan lembaga pendidikan menerapkan pembelajaran online atau distance learning yang dilakukan di rumah masing-masing.

Saat melaksanakan kegiatan pembelajaran online, guru dituntut untuk lebih inovatif dalam menyusun langkah-langkah pembelajaran. Perubahan metode cara pengajaran telah mengubah guru dan siswa dari pembelajaran tatap muka di kelas menjadi pembelajaran online. Meskipun pembelajaran dilakukan secara online, masih dimungkinkan untuk melakukan penilaian proses terhadap prestasi belajar siswa, dan guru tetap dapat memberikan penilaian dan tes kepada siswa untuk mengukur kemampuan dan pemahaman siswa terhadap mata pelajaran. Untuk melanjutkan proses belajar mengajar dan proses kelas meskipun siswa berada di rumah, aplikasi Zoom Cloud meeting sangat diperlukan.

Zoom Cloud Meeting adalah aplikasi yang dapat membantu dan mempermudah memenuhi kebutuhan berkomunikasi dengan banyak orang kapan saja, di mana saja, tanpa harus bertatap muka langsung. Aplikasi zoom ini membutuhkan perangkat pendukung seperti laptop atau handphone, dan tentunya harus terkoneksi dengan internet. Dengan menggunakan aplikasi zoom sebagai tempat belajar, guru dapat menciptakan suasana belajar yang tidak jauh berbeda dengan pembelajaran di sekolah (Sunami \& Aslam, 2021). Penggunaan aplikasi zoom dapat diintegrasikan dengan model pembelajaran yang sesuai. Model pembelajaran merupakan salah satu faktor utama dalam proses pembelajaran (Putri \& Taufina, 2020). Hal ini karena dengan memilih dan menerapkan model pembelajaran yang digunakan guru untuk mengajar, diharapkan proses pembelajaran akan lebih efektif mencapai tujuan pembelajaran yang diharapkan, dan prestasi akademik siswa juga akan meningkat. Karena hasil belajar adalah hasil belajar yang diperoleh siswa setelah mengikuti proses belajar mengajar guru (Meilana et al., 2021).

Dari berbagai mata pelajaran ilmu pengetahuan alam pada materi Zat Tunggal dan Zat Campuran merupakan bagian materi yang dianggap susah, membosankan, kurang interaktif, dan kurang menarik antusias siswa untuk belajar (Andriana et al., 2020). Hal tersebut bisa dikatakan pemicu terjadinya karena kreatifitas guru yang kurang efektif dalam proses mengajar sehingga siswa kurang termotivasi untuk belajar dan hal tersebut merupakan faktor penyebab terjadinya prestasi belajar siswa rendah (Simamora et al., 2020). Sikap aktif dan kreatif pendidik dapat diterapkan dalam kegiatan belajar menggunakan model pembelajaran yang bervariasi. Salah satu model pembelajaran yang dapat diaplikasikan pada pembelajaran IPA adalah model pembelajaran picture and picture. Model pembelajaran picture and picture, menemapatkan gambar sebagai fokus utama. Menurut Shoimin (dalam Febriyanti, 2017) gambar sangat penting untuk memperjelas materi yang diajarkan.

Model pembelajaran picture and picture adalah model pembelajaran yang menggunakan gambar yang dipasangkan atau di susunkan dalam susunan yang logis. Fokus pembelajaran melalui model ini adalah gambar sebagai media dalam proses pengajaran. Gambar-gambar yang disajikan atau disampaikan menjadi faktor utama dalam proses pembelajaran karena siswa akan belajar memahami konsep atau fakta dengan cara mendeskripsikan dan menghitung gambar-gambar yang diberikan kepadanya berdasarkan ide atau gagasannya. Dalam proses pembelajaran, penggunaan media gambar dapat memberikan kesempatan 
3020 Pengaruh Model Pembelajaran Picture and Picture Terhadap Peningkatan Prestasi Belajar Siswa Sekolah Dasar - Dista Praseptia, Zulherman

DOI: https://doi.org/10.31004/edukatif.v3i5.1073

kepada siswa untuk secara aktif dan kreatif menemukan sendiri materi pembelajaran dengan bantuan guru (Munawaroh \& Rofi'ah, 2017).

Berdasarkan penjelasan tersebut dan hasil wawancara yang dilakukan oleh SDN Susukan 02 Pagi tentang apa yang terjadi selama proses pembelajaran saat ini khususnya pada mata pelajaran IPA, prestasi akademik siswa menurun karena guru hanya menggunakan metode pengajaran yang membuat siswa merasa menjadi jenuh dan membosankan. Guru belajar lebih banyak tentang keterampilan setiap siswa melalui model pembelajaran gambar. memberdayakan siswa untuk berpikir logis dan sistematis, memungkinkan mereka memperoleh kebebasan untuk berpikir dan berlatih, dan membantu siswa belajar berpikir untuk mengembangkan pembelajaran yang lebih baik. Siswa Berpartisipasi langsung dalam perencanaan dan pengelolaan kelas. Tujuan dari penelitian ini adalah untuk mengetahui Pengaruh model pembelajaran picture and picture terhadap peningkatan prestasi belajar siswa sekolah dasar pada materi zat tunggal dan zat campuran (Istianah et al., 2019).

Dalam kajian (Wahyudi et al., 2021) model pembelajaran picture and picture adalah model pembelajaran yang ditekankan pada gambar yang disusunkan menjadi susunan yang tepat, dan dapat mengembangkan interaksi antar siswa. Model pembelajaran ini memiliki sifat aktif, inovatif, kreatif, dan menyenangkan. Gambar-gambar tersebut menjadi faktor utama dalam proses pembelajaran. Oleh karena itu, sebelum proses pembelajaran, guru menyiapkan gambar yang akan ditampilkan dalam bentuk kartu, atau jika sekolah sudah menggunakan teknologi canggih, Anda dapat menggunakan Power Point atau perangkat lunak lainnya. Dari sudut pandang tersebut, dapat disimpulkan bahwa model pembelajaran picture and picture adalah model pembelajaran yang menggunakan gambar, dan gambar akan diurutkan sehingga berada dalam urutan yang logis/benar.

Prestasi belajar menurut (Syafi'i et al., 2018) adalah Hasil belajar yang dilihat dari akibat proses pembelajaran dibuktikan dengan nilai atau angka dalam bentuk materi yang telah dipelajari sesuai dengan tujuan yang telah ditentukan. Sedangkan menurut (Akhwani \& Nurizka, 2021) Prestasi belajar merupakan tujuan akhir dari penyelenggaraan pembelajaran di sekolah, dan juga merupakan tujuan terpenting. Setiap prestasi siswa dapat disajikan dalam bentuk hasil tes kemampuan akademik. Dari sudut pandang ini dapat disimpulkan bahwa prestasi belajar adalah serangkaian kegiatan yang dilakukan seseorang berdasarkan hasil yang telah dicapai, dan hasil tersebut dapat berupa nilai.

Ilmu Pengetahuan Alam menurut (Marsiyam, 2021) adalah pengetahuan tentang fenomena alam. Mereka fokus pada fakta, konsep, prinsip dan penemuan terkait fenomena alam yang terjadi di sekitarnya, dengan tujuan mengembangkan kehidupan sehari-hari dan bermanfaat bagi siswa. Dalam kehidupan, siswa dapat menanamkan rasa ingin tahu dan sikap positif terhadap pembelajaran IPA. Sedangkan menurut (Zulherman et al., 2020) mengatakan bahwa pembelajaran IPA adalah ilmu yang secara sistematis mempelajari alam dan isinya serta peristiwa alam yang terjadi dalam proses sains untuk membentuk cara pandang baru. Berdasarkan penjelasan tersebut, dapat disimpulkan bahwa ilmu pengetahuan alam (IPA) adalah ilmu yang mempelajari semua benda yang ada di alam, peristiwa dan gejala yang terjadi di alam.

Pada mata pelajaran IPA, materi yang digunakan untuk penelitian adalah zat tunggal dan zat campuran. Zat tunggal adalah zat yang terdiri dari satu zat, seperti air, kapur, besi logam, kawat tembaga, garam, gula emas, dll. Zat tunggal memiliki ciri tidak dapat diuraikan lagi menjadi zat yang lebih sederhana. Zat campuran adalah zat yang tersusun dari beberapa zat, atau zat tunggal yang masih memiliki sifat-sifat zat penyusunnya. Campuran dapat dibedakan menjadi dua jenis, yaitu campuran homogen dan campuran heterogen. Campuran zat dapat memiliki sifat yang berbeda sesuai dengan zat yang menyusunnya (Subekti, 2017).

Berdasarkan penjelasan secara ringkas diatas dapat diketahui bahwa model pembelajaran picture and picture merupakan pemilihan yang tepat bagi siswa untuk memahami isi pelajaran IPA pada materi zat tunggal dan zat campuran, serta cara untuk meningkatkan prestasi belajar siswa. Maka dari itu 
peneliti melakukan penelitian pengaruh model pembelajaran picture and picture terhadap peningkatan prestasi belajar siswa sekolah dasar pada materi zat tunggal dan zat campuran. Manfaat dari penelitian ini yaitu dapat memperluas ilmu atau sebagai sumber pustaka khususnya dalam bidang pendidikan yang berkaitan dengan model pembelajaran picture and picture terhadap peningkatan prestasi belajar siswa sekolah dasar.

Penelitian terdahulu membahas tentang model pembelajaran picture and picture, (Holiah, 2019) menyatakan didalam penelitiannya bahwa pembelajaran yang dilakukan secara langsung membuat siswa aktif dan bersemangat sehingga prestasi belajar meningkat. Tetapi pada kondisi sekarang yang mengharuskan belajar online atau pembelajaran jarak jauh, maka muncul ide apakah ketika model pembelajaran picture and picture diterapkan secara online dapat membuat hasil yang memuaskan seperti pada penelitian sebelumnya. Berdasarkan apa yang telah dipaparkan, model pembelajaran picture and picture efektif diterapkan dimasa pembelajaran jarak jauh saat ini.

\section{METODE PENELITIAN}

Metode yang digunakan dalam penelitian ini adalah metode kuantitatif eksperimen (quasi experiment). (Hastjarjo, 2019) dimana dalam prosesnya bertujuan untuk mengetahui pengaruh suatu treatment (perlakuan) tertentu terhadap suatu kelas yang diberikan perlakuan, serta menguji hipotesis penelitian yang sudah peneliti tetapkan. Desain dalam penelitian ini menggunakan Pretest-Posttest control group design. Dengan desain ini kelompok eksperimen atau kelompok kontrol dipilih secara random (Siregar, 2018). Desain penelitiannya adalah sebagai berikut :

Tabel 1. Desain Penelitian

\begin{tabular}{cccc}
\hline Kelompok & Pretest & Perlakuan & Posttest \\
\hline Eksperimen (VA) & $O_{1}$ & $\mathrm{X}$ & $O_{2}$ \\
\hline Kontrol (VB) & $O_{3}$ & - & $O_{4}$ \\
\hline
\end{tabular}

Keterangan :

$\mathrm{O}_{1}:$ Pretest kelompok eksperimen

$\mathrm{O}_{2}$ : Posttest kelompok eksperimen

$\mathrm{O}_{3}$ : Pretest kelompok kontrol

$\mathrm{O}_{4}:$ Posttest kelompok kontrol

$\mathrm{X}$ : Penggunaan model pembelajaran picture and picture.

Populasi yang digunakan dalam penelitian ini adalah populasi siswa kelas V SDN Susukan 02 Pagi. Sampel dalam penelitian ini adalah siswa kelas V-A dan V-B SDN Susukan 02 Pagi yang berjumlah 60 siswa. Peneliti menggunakan teknik pemilihan sampel random sampling. Sampel yang diambil adalah salah satu kelas berdasarkan proses pengundian yaitu siswa kelas V-A yang terdiri dari 30 siswa sebagai kelas eksperimen dan kelas V-B yang berjumlah 30 siswa sebagai kelas kontrol. Teknik pengambilan datanya menggunakan tes yang diberikan melalui google from. Dalam pengolahan data penelitian diukur dengan uji validitas dan reabilitas untuk mendapatkan soal yang valid ataupun tidaknya suatu butir tes dengan menggunakan rumus product momen. Teknik analisis data prestasi belajar siswa yaitu uji normalitas menggunakan uji liliefors, uji homogenitas menggunakan uji fisher, dan hipotesis menggunakan uji-t. 
3022 Pengaruh Model Pembelajaran Picture and Picture Terhadap Peningkatan Prestasi Belajar Siswa Sekolah Dasar - Dista Praseptia, Zulherman

DOI: https://doi.org/10.31004/edukatif.v3i5.1073

\section{HASIL DAN PEMBAHASAN PENELITIAN}

Sebelum dilakukan penelitian, diperlukan untuk uji coba instrumen tes yang akan disebarkan kepada siswa. Tujuan diadakan uji coba validitas instrumen untuk dapat melihat butir valid atau tidaknya dalam sebuah instrumen. Uji validitas dari instrumen angket diketahui siswa berjumlah 39 dan total keseluruhan butir soal sebanyak 30. Setelah diperhitungkan jumlah tes yang valid sebanyak 25 soal, sebagian butir tes tidak valid karena rhitung > rtabel. Hasil uji validitas diperoleh sebanyak 25 soal yang dinyatakan valid.

Selanjutnya setelah uji validitas dilakukan uji reliabilitas instrumen terhadap 25 soal yang telah valid dan dipilih. Dan berdasarkan perhitungan hasilnya didapatkan rhitung $=0,891$ dan rtabel $=0,316$. Karena rhitung > rtabel maka instrumen tersebut dinyatakan reliabel dan layak untuk digunakan pada penelitian.

Kegiatan penelitian ini dilakukan di SDN Susukan 02 Pagi pada kelas VA sebagai kelas eksperimen dan VB sebagai kelas kontrol. Penilaian prestasi belajar dilakukan dengan memberikan soal IPA materi zat tunggal dan zat campuran sebelum dan setelah perlakuan. Setiap soal tes berjumlah 25 soal. Hasil dari statistik deskriptif hasil belajar terdapat peningkatan di kelas eksperimen yang menggunakan model pembelajaran picture and picture melalui aplikasi zoom dan kelas kontrol yang menggunakan materi biasa berupa tulisan. Hasil dari data yang diteliti adalah sebagai berikut:

Tabel 2. Analisis statistik dari nilai prestasi belajar pada kelas eksperimen dan kelas kontrol

\begin{tabular}{lcccc}
\hline \multirow{2}{*}{ Statistik } & \multicolumn{4}{c}{ Nilai Statistik } \\
\cline { 2 - 5 } & Pretest & Posttest & Pretest & Posttest \\
\cline { 2 - 5 } & 30 & 30 & 30 & 30 \\
\hline Jumlah Siswa & 40 & 72 & 40 & 52 \\
\hline Nilai Terendah & 80 & 96 & 80 & 84 \\
\hline Nilai Tertinggi & 66,8 & 85 & 62,4 & 66,2 \\
\hline Rata-rata & 10,82 & 7,3 & 10,2 & 8,04 \\
\hline Simpangan Baku & & & & \\
\hline
\end{tabular}

Uji normalitas dilakukan untuk menguji apakah semua variabel berdistribusi normal atau tidak. Uji normalitas ini menggunakan uji liliefors. Hasil uji normalitas tersebut disajikan pada tabel dibawah ini.

Tabel 3. Uji Normalitas

\begin{tabular}{|c|c|c|c|c|}
\hline Nilai & $L_{\text {hitung }}$ & $L_{\text {tabel }}$ & Kriteria & Keterangan \\
\hline Pretest Kelas Eksperimen & 0,111 & \multirow{4}{*}{0,161} & \multirow{4}{*}{$L_{\text {hitung }}<L_{\text {tabel }}$} & \multirow{4}{*}{ Normal } \\
\hline Posttest Kelas Eksperimen & 0,158 & & & \\
\hline Pretest Kelas Kontrol & 0,082 & & & \\
\hline Posttest Kelas Kontrol & 0.148 & & & \\
\hline
\end{tabular}

Berdasarkan tabel di atas, terlihat bahwa data pretest dan posttest prestasi belajar kelas eksperimen maupun kelas kontrol menunjukkan bahwa Lhitung $<$ Ltabel pada taraf signifikan $\alpha=0,05$, maka dapat disimpulkan data kelas eksperimen dan kelas kontrol berdistribusi normal.

Uji homogenitas dua varians antar nilai Pretest eksperimen dan kontrol, serta nilai Posttest eksperimen dan kontrol menggunakan uji Fisher.

Tabel 4. Uji Homogenitas

\begin{tabular}{|c|c|c|c|c|}
\hline Kelompok & Fhitung & Ftabel & Kriteria & Keterangan \\
\hline Pretest & 1,15884 & \multirow{2}{*}{1,85835} & \multirow{2}{*}{ Fhitung < Ftabel } & \multirow{2}{*}{ Homogen } \\
\hline Posttest & 1,19925 & & & \\
\hline
\end{tabular}


3023 Pengaruh Model Pembelajaran Picture and Picture Terhadap Peningkatan Prestasi Belajar Siswa Sekolah Dasar - Dista Praseptia, Zulherman

DOI: https://doi.org/10.31004/edukatif.v3i5.1073

Berdasarkan tabel di atas, diperoleh nilai Ftabel sebesar 1,85835 dan harga Fhitung Pretest sebesar 0,86293 dan Fhitung Posttest 1,19925 dengan dk pembilang $=29$, dk penyebut $=29$ dan taraf signifikan $\alpha$ $=0,05$. Dikarenakan Fhitung < Ftabel, maka dapat disimpulkan bahwa data tersebut bersifat homogen.

Dari data penelitian, diperoleh nilai rata-rata pada kelas eksperimen adalah 85 dengan simpangan baku 7,3. Sedangkan nilai rata-rata pada kelas kontrol 66,2 dengan simpangan baku 8. Untuk mengetahui apakah perbedaan rata-rata tersebut disebabkan akibat perbedaan perlakuan atau hanya kebetulan, maka diperlukan analisis lebih lanjut.

Dari dilihat dari hasil pengujian persyaratan analisis yang meliputi uji normalitas dan uji homogenitas, dapat diketahui bahwa nilai kelas eksperimen dan kelas kontrol tersebut berada pada distribusi normal dan bersifat homogen sehingga dapat menguji hipotesis penelitian dengan uji-t.

Tabel 5. Hasil Uji-t

\begin{tabular}{lcccccc}
\hline Kelompok & Rerata & Sgab & Dk & $\boldsymbol{t}_{\text {hitung }}$ & $\boldsymbol{t}_{\text {tabel }}$ & Keterangan \\
\cline { 1 - 2 } Eksperimen & 85 & \multirow{2}{*}{15,39} & 58 & 4,9414 & 2,0021 & $t_{\text {hitung }}>t_{\text {tabel }}$ \\
\cline { 1 - 2 } & 66,2 & & & & & \\
\hline
\end{tabular}

Berdasarkan tabel di atas, hasil perhitungan uji-t pada penelitian ini diperoleh thitung $=4,9414$ pada taraf signifikan $\alpha=0,05$ dengan derajat kebebasan $(\mathrm{dk})=58$ seharga 2,0021. Dikarenakan thitung lebih besar dari ttabel ( 4,9414 > 2,0021 ) maka dapat disimpulkan bahwa Ho ditolak dan H1 diterima yang menunjukkan bahwa hipotesis penelitian diterima berarti terdapat Pengaruh Model Pe mbelajaran Picture and Picture Terhadap Peningkatan Prestasi Belajar Siswa Sekolah Dasar Pada Materi Zat Tunggal dan Zat Campuran.

Hasil penelitian ini sekaligus membuktikan bahwa terdapat pengaruh bukan suatu kebetulan, tetapi karena adanya suatu perlakuan yang diberikan pada kelas eksperimen tersebut. Hal ini terlibat dari nilai ratarata kelas V-A sebagai kelas eksperimen dengan menerapkan model pembelajaran picture and picture lebih tinggi yaitu 85 dengan nilai tertinggi 96 dan nilai terendah 72. Sedangkan nilai rata-rata kelas V-B sebagai kelas kontrol yaitu 66 dengan nilai tertinggi 84 dan nilai terendah 52. Hasil penelitian ini membuktikan bahwa hampir seluruh siswa kelas eksperimen yang menerapkan model pembelajaran picture and picture mendapatkan nilai di atas KKM. Dengan demikian dapat dikatakan bahwa model pembelajaran picture and picture telah berhasil diterapkan pada proses pembelajaran sehingga terjadi peningkatan prestasi belajar siswa.

Penelitian ini serupa dengan penelitian yang dilakukan (Rahmi \& Yuswanti, 2021) bahwa pembelajaran dengan penerapan model pembelajaran picture and picture juga termasuk pada pembelajaran aktif karena dapat meningkatkan aktifitas dan motivasi belajar siswa. Hal serupa juga ditemukan (Marlina, 2020) bahwa model pembelajaran picture and picture dapat diterapkan dalam pembelajaran IPA sebagai upaya untuk meningkatkan prestasi belajar siswa sekolah dasar. Dan juga pada penelitian (Khotimah, 2019) menyatakan hasil pada penelitian terdapat peningkatan belajar siswa dengan menggunakan model pembelajaran picture and picture.

Keterbatasan yang dialami pada proses penelitian ini yaitu semua peserta didik dan orangtua kurang menguasai cara menggunakan aplikasi zoom, serta jaringan yang kurang baik mengakibatkan komunikasi atau interaksi guru dengan peserta didik sedikit terganggu saat guru sedang menggunakan model pembelajaran picture and picture pada proses pembelajaran. Penyelesaian yang dapat dilakukan yaitu guru harus mempersiapkan proses pembelajaran yang lebih baik agar dapat mengurangi kendala yang terjadi pada saat pembelajaran berlangsung. 
3024 Pengaruh Model Pembelajaran Picture and Picture Terhadap Peningkatan Prestasi Belajar Siswa Sekolah Dasar - Dista Praseptia, Zulherman

DOI: https://doi.org/10.31004/edukatif.v3i5.1073

\section{KESIMPULAN}

Berdasarkan perhitungan data yang dilakukan, peneliti menyimpulkan bahwa kelas dengan model pembelajaran picture and picture lebih unggul dibandingkan kelas yang tidak diberi perlakuan model pembelajaran picture and picture. Prestasi belajar IPA siswa pada materi zat tunggal dan zat campuran, nilai rata-rata setelah pengujian di kelas eksperimen dengan model pembelajaran picture and picture berjumlah 85. Sedangkan rata-rata nilai setelah dilakukan pengujian dikelas kontrol tanpa model pembelajaran picture and picture adalah 66,2. Berdasarkan uji hipotesis uji-t, hasil thitung lebih besar daripada ttabel perihal ini menunjukkan bahwa $\mathrm{H} 1$ diterima yang artinya model pembelajaran picture and picture memiliki pengaruh yang signifikan terhadap prestasi belajar siswa sekolah dasar pada materi zat tunggal dan zat campuran.

\section{DAFTAR PUSTAKA}

Akhwani, \& Nurizka, R. (2021). Meta-Analisis Quasi Eksperimental Model Pembelajaran Value Clarification Technique (VCT) Terhadap Prestasi Belajar Siswa Sekolah Dasar. Jurnal Basicedu, 5(2), 1060-1066. Https://Doi.Org/Https://Doi.Org/10.31004/Basicedu.V5i2.706

Andriana, E., Ramadayanti, S., \& Noviyanti, T. E. (2020). Pembelajaran Ipa Di Sd Pada Masa Covid 19. Journal Of Chemical Information And Modeling, 43(1), 7728.

Hastjarjo, T. D. (2019). Rancangan Eksperimen-Kuasi. Jurnal Buletin Psikologi, 27(2), 187. Https://Doi.Org/10.22146/Buletinpsikologi.38619

Holiah. (2019). Peningkatan Prestasi Belajar Bahasa Indonesia Melalui Penerapan Model Pembelajaran Picture And Picture Siswa Kelas Vi Sdn 2 Lenek. Jurnal Edukasi Dan Sains, 1(1), 40-52. Https://Ejournal.Stitpn.Ac.Id/Index.Php/Edisi

Istianah, E., H, D. E., \& P, S. A. (2019). Analisis Faktor Keberhasilan Prestasi Belajar Ipa Di Sekolah Dasar. JANACITTA : Journal Of Primary And Children's Education, 2(024). Http://Jurnal.Unw.Ac.Id/Index.Php/Janacitta

Khotimah, K. (2019). Pengaruh Model Kooperatif Tipe Picture And Picture Terhadap Hasil Belajar IPA Materi Lingkungan Sehat Dan Lingkungan Tidak Sehat Di Kelas III MI An-Nur Kota Cirebon Khusnul. $\begin{array}{lllll}\text { Indonesian Journal Of Elementary } & \text { Education, }\end{array}$ Http://Www.Syekhnurjati.Ac.Id/Jurnal/Index.Php/Ijee/

Marlina, L. (2020). Kajian Pengaruh Penggunaan Model Pembelajaran Picture And Picture Terhadap Prestasi Belajar IPA Siswa Sekolah Dasar. Ainara Journal (Jurnal Penelitian Dan Pengabdian Kepada Masyarakat Bidang Ilmu Pendidikan), $\quad$ 1(November), 56-61. Http://Journal.Ainarapress.Org/Index.Php/Ainj

Marsiyam. (2021). Peningkatan Prestasi Belajar IPA Tentang Cara Menghasilkan Energi Listrik Melalui Pendekatan Kontekstual Pada Siswa Kelas VI SDN 008 Nongsa Batam. Pedagogia: Jurnal Ilmiah Pendidikan Dasar Indonesia, 3(1), 59-70.

Meilana, S. F., Aulia, N., Zulherman, \& Aj, G. B. (2021). Pengaruh Model Pembelajaran Think Pair Share (TPS) Terhadap Kemampuan Berpikir Kritis Di Sekolah Dasar. Jurnal Basicedu, 5(2), 1060-1066.

Monica, J., \& Fitriawati, D. (2020). Efektivitas Penggunaan Aplikasi Zoom Sebagai Media Pembelajaran Online Pada Mahasiswa Saat Pandemi Covid-19. Jurnal Communio : Jurnal Ilmu Komunikasi, 9(2), 1630-1640. Https://Doi.Org/10.35508/Jikom.V9i2.2416

Munawaroh, M., \& Rofi'ah. (2017). Pengaruh Model Pembelajaran Kooperatif Picture And Picture Terhadap Hasil Belajar Siswa Pada Mata Pelajaran Ipa Di Kelas Iii Di Mi Tarbiyatusshibyan. 1(2), 94111.

Putri, A., \& Taufina, T. (2020). Peningkatan Hasil Belajar Menggunakan Model Cooperative Tipe Picture And Picture Di Sekolah Dasar. Jurnal Basicedu, 4(3), 644-648. 
3025 Pengaruh Model Pembelajaran Picture and Picture Terhadap Peningkatan Prestasi Belajar Siswa Sekolah Dasar - Dista Praseptia, Zulherman

DOI: https://doi.org/10.31004/edukatif.v3i5.1073

Https://Doi.Org/10.31004/Basicedu.V4i3.415

Rahmi, L., \& Yuswanti, D. (2021). Meningkatan Motivasi Belajar Menggunakan Model Pembelajaran Picture And Picture Pada Mata Pelajaran Ilmu Pengetahuan Alam. Judha_PGSD: Jurnal Dharma PGSD, 1(2), 73-85. Http://Ejournal.Undhari.Ac.Id/Index.Php/Judha

Simamora, T., Harapan, E., \& Kesumawati, N. (2020). Faktor-Faktor Determinan Yang Mempengaruhi Prestasi Belajar Siswa. JMKSP (Jurnal Manajemen, Kepemimpinan, Dan Supervisi Pendidikan), 5(2), 191. Https://Doi.Org/10.31851/Jmksp.V5i2.3770

Siregar, S. (2018). Metode Penelitian Kuantitatif. Kencana Prenda Media Group.

Subekti, A. (2017). Benda-Benda Di Sekitar Kita, Buku Tematik Terpadu Kurikulum 2013.

Sunami, M. A., \& Aslam. (2021). Pengaruh Penggunaan Media Pembelajaran Video Animasi Berbasis Zoom Meeting Terhadap Minat Dan Hasil Belajar IPA Siswa Sekolah Dasar. Jurnal Basicedu, 5(2), 10601066.

Syafi'i, A., Marfiyanto, T., \& Rodiyah, S. K. (2018). Studi Tentang Prestasi Belajar Siswa Dalam Berbagai Aspek Dan Faktor Yang Mempengaruhi. Jurnal Komunikasi Pendidikan, 2(2), 115. Https://Doi.Org/10.32585/Jkp.V2i2.114

Wahyudi, G., R, S., \& Arief, D. (2021). Pengembangan Bahan Ajar Tematik Berbasis Model Picture And

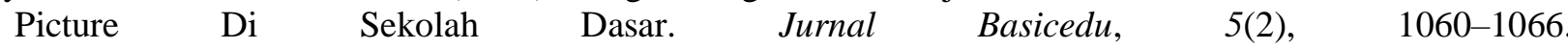
Https://Doi.Org/Https://Doi.Org/10.31004/Basicedu.V5i2.814 ISSN

Zulherman, Z., Arifudin, R., \& Pratiwi, M. S. (2020). Pengaruh Model Pembelajaran Auditory, Intellectuality, Repetition (AIR) Untuk Siswa Sekolah Dasar. Jurnal Basicedu, 4(4), 1267-1266. Https://Doi.Org/10.31004/Basicedu.V4i4.546 